\title{
Polar bears observed climbing steep slopes to graze on scurvy grass in Svalbard
}

\author{
Lech Stempniewicz
}

Department of Vertebrate Ecology and Zoology, Faculty of Biology, University of Gdańsk, Gdańsk, Poland

\begin{abstract}
It is well known that polar bears feed on vegetation. Here, I report novel observations of polar bears grazing on polar scurvy grass (Cochlearia groenlandica) at the foot of a large seabird colony on a cliff on Spitsbergen, Svalbard, in the summers of 2005, 2006, 2009, 2014 and 2015. Why they choose such energy-costly climbing to feed on plants is not clear. One possibility is that they may be suffering from vitamin $C$ deficiency and are searching for this particular plant, which has a high level of this vitamin. Another, but not exclusive reason, is that vegetation containing scurvy grass is abundant enough to be efficiently grazed by such unspecialized plant-eaters as polar bears only on such relatively inaccessible, steep slopes below seabird colonies. Most of the lowland and gently sloping tundra areas in Svalbard are overgrazed by geese and reindeer, the populations of which have increased considerably as a consequence of climate amelioration. Large seabird colonies are known to attract animals from different trophic levels, but this is the first description of their attractiveness to polar bears as grazing areas.
\end{abstract}

\section{KEYWORDS}

Carnivores feeding on vegetation; Ursus maritimus; diet; Cochlearia groenlandica; Svalbard
The polar bear (Ursus maritimus) is considered a specialist hunter primarily of seals (Derocher et al. 2002). They have also been observed to kill small whales such as belugas (Delphinapterus leucas), narwhals (Monodon monoceros) and white-beaked dolphins (Lagenorhynchus albirostris) when these have become trapped in sea ice (Smith \& Sjare 1990; Aars et al. 2015). However, according to modern taxonomic classification, the polar bear is a sister species to the opportunistic omnivorous brown bear (Ursus arctos) (Wozencraft 2005) and under some circumstances, for example when stranded on land, appear to be quite opportunistic. They will consume a wide variety of other foods, including ungulates like muskox (Ovibos moschatus) and reindeer (Rangifer tarandus), birds, eggs, rodents and crustaceans, and other polar bears (Lunn \& Stirling 1985; Stempniewicz 1993, 2006; Donaldson et al. 1995; Derocher et al. 2002; Derocher 2012; Stempniewicz et al. 2014; Prop et al. 2015). However, none of these animals make up a significant part of their diet (Russell 1975; Derocher et al. 2000; Brook \& Richardson 2002). It is thought that polar bears cannot derive sufficient caloric intake from terrestrial food (Ramsay \& Hobson 1991; Rode et al. 2015). However, Gormezano and Rockwell (2015) have calculated that the probability of land-locked polar bears surviving climate change depends largely on the duration of the ice-free season and local availability of novel high-energy terrestrial foods (geese, eggs, caribou). If polar bears can adapt their foraging behaviour to effectively exploit these resources, predictions for starvation-related mortality may be overestimated.

Both marine and terrestrial plants are part of the polar bear diet. Russell (1975) suggests that they may seek plants even when animal food is plentiful. The most common plant food is kelp (Fucus spp. and Laminaria spp.), eaten presumably as a source of vitamins and minerals. Different grass species, including Lyme grass (Leymus arenarius), are the most common terrestrial plants taken by bears. Depending on the locality, polar bears consume different kinds of carbohydrate-rich berries (Empetrum nigrum, Vaccinium spp. and Juniperus communis). They take the leaves and stems of shrubs and herbs in trace amounts only. Mosses and mushrooms are occasionally eaten in considerable quantities, possibly as a source of vitamins and minerals (Russell 1975). Though common throughout the European and American Arctic, polar scurvy grass (Cochlearia groenlandica) has not yet been mentioned in the available literature as a component of the polar bear's diet (Derocher 2012; Gormezano \& Rockwell 2013a, b).

Polar scurvy grass, which belongs to the Family Brassicaceae (Cruciferae), is a common plant growing along the entire Svalbard coast, and is characterized 
by its high vitamin $\mathrm{C}$ content. Inuit people, experienced polar explorers and trappers knew of the remedial antiscorbutic features of the plant and used it accordingly (Aiken et al. 2007). Owing to its tolerance to high nutrient levels in the soil, scurvy grass is most abundant in the vicinity of well fertilized seabird colonies (Eurola \& Hakala 1977; Ellis et al. 2011; Zmudczynska-Skarbek et al. 2013; Wojciechowska et al. 2015).

It is well known that large seabird colonies in the Arctic, surrounded by highly productive ornithogenic tundra, attract various species of herbivores - such as geese and reindeer - scavengers and predators - e.g., glaucous gulls (Larus hyperboreus), Arctic foxes (Vulpes lagopus) and polar bears - searching for easily available plant and animal food (Stempniewicz 1990; Jakubas et al. 2008; Zwolicki et al. 2013, 2016). However, the attractiveness of such areas for plant grazing by polar bears has not been described.

\section{Observations}

During fieldwork in July and August 2005, 2006, 2009, 2014 and 2015, one to three polar bears were observed each summer grazing on polar scurvy grass on the talus slope below the large kittiwake (Rissa tridactyla) and Brünnich's guillemot (Uria lomvia) colony at Gnåloden $\left(77^{\circ} 01^{\prime} \mathrm{N} 15^{\circ} 52^{\prime} \mathrm{E}\right)$, Hornsund, south-west Spitsbergen. The remains of birds (eggs, chicks, dead/injured adults) are readily discovered at the foot of the cliff colony, but the bears climbed high up on the steep talus slope (inclination $45-50^{\circ}$ ) and were focusing on the wide zone of lush vegetation several metres below the foot of the colony (Fig. 1). They had apparently come there in order to graze on scurvy grass where it was most abundant, ca. 10-30 m below the foot of the colony. There, scurvy grass reaches its largest individual size and highest density and biomass, all of which then decline towards the shore (Zmudczynska-Skarbek et al. 2013). The calorific value of the plants occurring there was enhanced as the majority of them were flowering and producing seeds (Wojciechowska et al. 2015). The grazing bears were moving along the horizontal strip of the dense, sturdy plants (Fig. 1). Having traversed the slope, the bears left large patches of grazed scurvy grass plants behind. All 17 fresh polar bear faeces sampled in the area contained exclusively scurvy grass remnants.

\section{Discussion}

The large-scale shrinking of sea ice reported in recent decades in the Arctic (Kwok et al. 2009; Onarheim et al. 2014) has reduced the area of natural polar bear hunting habitat and has forced some bears to search for terrestrial food (Ramsay \& Hobson 1991; Prop et al. 2015). The consequence of this is an evident long-term decline in their body condition (Stirling \& Derocher 2012; Obbard et al. 2016; Tartu et al. 2016). Most mammals can produce vitamin C endogenously based on the food they ingest. In the case of predators, the fresh meat and fat of their prey are natural sources. For polar bears, blubber, skin and, especially, liver, where ascorbic acid is synthesized, provided by seals, their staple prey, are the most important natural
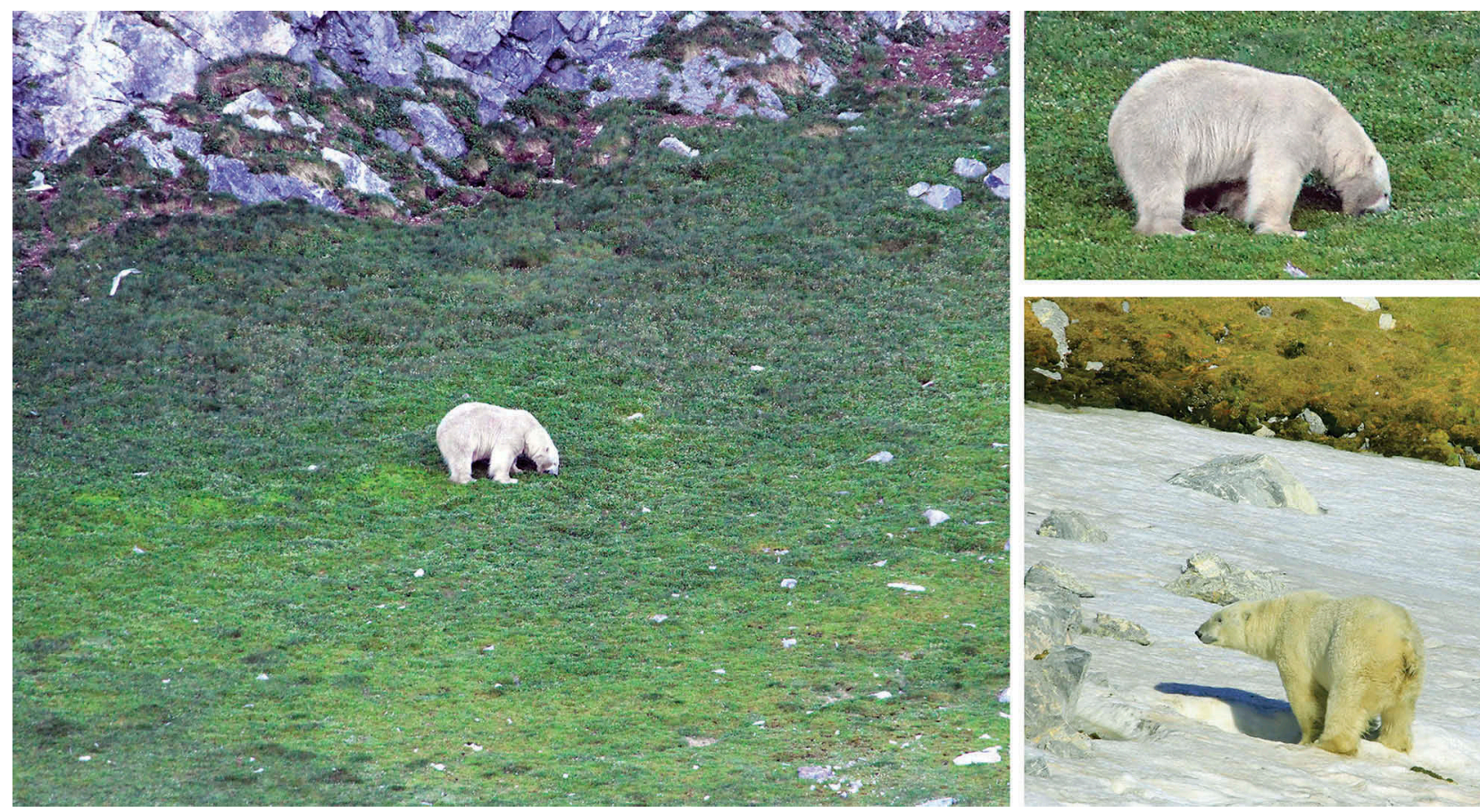

Figure 1. Polar bear grazing on polar scurvy grass below the seabird colony in Hornsund; another individual defecating below the bird cliff after feeding on scurvy grass. 
sources of the vitamin, comparative to those found in blueberries (Vaccinium uliginosum) (Fediuk et al. 2002). However, the rate of vitamin $C$ synthesis in liver tissue is lower in some carnivores, e.g., dogs, compared to other animals (Chatterjee et al. 1975) and consequently, vitamin $\mathrm{C}$ has been given as a supplement even to healthy well-fed dogs (Hesta et al. 2008). We may speculate that polar bears remaining on land, where they have very limited access - if any - to seals and have been starving/ fasting for a long time, may suffer from a deficiency of vitamin C.

Polar scurvy grass occurs widely in Svalbard, but apart from the areas near the colony of piscivorous birds, the plants are usually sparsely distributed and short, no taller than $3 \mathrm{~cm}$ (Wojciechowska et al. 2015). Moreover, the climate-induced increase in the populations of geese and reindeer in Svalbard observed in recent decades has led to overgrazing of the lowland tundra vegetation (Olofsson 2006; Aubry et al. 2013). As a result most plants easily grazed by herbivores barely protrude above the ground, which makes them inaccessible to polar bears. It remains undetermined whether polar bears select scurvy grass because of its high vitamin $\mathrm{C}$ content or are searching for sites with any soft tissue plant abundant enough for grazing and the scurvy grass growing at the foot of the seabird colonies best meets this condition.

\section{Disclosure statement}

No potential conflict of interest was reported by the author.

\section{Funding}

The study was supported by funds from Poland through the Polish Ministry of Science and Higher Education (IPY/ 25/2007) and from Norway through the Norwegian Financial Mechanism (ALKEKONGE, PNRF-234-AI-1/07 and GLAERE, POL-NOR/199377/91/2014).

\section{References}

Aars J., Andersen M., Brenière A. \& Blanc S. 2015. Whitebeaked dolphins trapped in the ice and eaten by polar bears. Polar Research 34, article no. 26612, doi: 10.3402/ polar.v34.26612

Aiken S.G., Dallwitz M.J., Consaul L.L., McJannet C.L., Boles R.L., Argus G.W., Gillett J.M., Scott P.J., Elven R., LeBlanc M.C., Gillespie L.J., Brysting A.K., Solstad H. \& Harris J.G. 2007. Flora of the Canadian Arctic Archipelago: descriptions, illustrations, identification, and information retrieval. Cochlearia groenlandica $L$. Ottawa: NRC Research Press, National Research Council of Canada. Accessed on the internet at http:// nature.ca/aaflora/data on 10 December 2016.

Aubry L.M., Rockwell R.F., Cooch E.G., Brook R.W., Mulder C.P. \& Koons D.N. 2013. Climate change, phenology, and habitat degradation: drivers of gosling body condition and juvenile survival in lesser snow geese. Global Change Biology 19, 149-160.

Brook R.K. \& Richardson E.S. 2002. Observations of polar bear predatory behaviour toward caribou. Arctic 55, 193-196.

Chatterjee I.B., Majumber A.K., Nandi B.K., \& Subramanian N. 1975. Synthesis and some major functions of vitamin C in animals. Annals of the New York Academy Of Sciences 258, 24-47.

Derocher A., Wiig Ø. \& Bangjord G. 2000. Predation of Svalbard reindeer by polar bears. Polar Biology 23, 675-678.

Derocher A.E. 2012. Polar bears. A complete guide to their biology and behaviour. Baltimore, MD: Johns Hopkins University Press.

Derocher A.E., Wiig Ø. \& Andersen M. 2002. Diet composition of polar bears in Svalbard and the western Barents Sea. Polar Biology 25, 448-452.

Donaldson G.M., Chapdelaine G. \& Andrews J.D. 1995. Predation of thick-billed murres, Uria lomvia, at two breeding colonies by polar bears, Ursus maritimus, and walruses, Odobenus rosmarus. Canadian Field-Naturalist 109, 112-114.

Ellis J., Bellingham P., Cameron D., Croll D., Kolb G., Kueffer C., Mittelhauser G.H., Schmidt S., Vidal E. \& Wait D.A. 2011. Effects of seabirds on plant communities. In Mulder C. et al. (eds.): Seabird islands. Ecology, invasion and restoration. Pp. 135-176. New York: Oxford University Press.

Eurola S. \& Hakala A. 1977. The bird cliff vegetation of Svalbard. Aquilo Seria Botanica 15, 1-18.

Fediuk K., Hidiroglou N., Madére R. \& Kuhnlein H.V. 2002. Vitamin $C$ in Inuit traditional food and women's diets. Journal of Food Composition and Analysis 15, 221-235.

Gormezano L.J. \& Rockwell R.F. 2013a. What to eat now? Shifts in terrestrial diet in western Hudson Bay. Ecology and Evolution 3, 3509-3523.

Gormezano L.J. \& Rockwell R.F. 2013b. Dietary composition and spatial patterns of polar bear foraging on land in western Hudson Bay. BMC Ecology 13, article no. 51, doi: $10.1186 / 1472-6785-13-51$

Gormezano L.J. \& Rockwell R.F. 2015. The energetic value of land-based foods in western Hudson Bay and their potential to alleviate energy deficits of starving adult male polar bears. PLoS One 10, article no. e0128520, doi: 10.1371/journal.pone.0128520

Hesta M., Ottermans C., Krammer-Lucas S., Zentek J., Helweg P., Buyse J., \& Janssens G.P.S. 2008. The effect of vitamin $C$ supplementation in healthy dogs on antioxidative capacity and immune parameters. Journal of Animal Physiology and Animal Nutrition 93, 26-34.

Jakubas D., Zmudczyńska K., Wojczulanis-Jakubas K. \& Stempniewicz L. 2008. Faeces deposition and numbers of vertebrate herbivores in the vicinity of planktivorous and piscivorous seabird colonies in Hornsund, Spitsbergen. Polish Polar Research 29, 45-58.

Kwok R., Cunningham G.F., Wensnahan M., Rigor I., Zwally H.J. \& Yi D. 2009. Thinning and volume loss of the Arctic Ocean sea ice cover: 2003-2008. Journal Geophysical Research-Oceans 114, article no. C07005, doi: 10.1029/2009JC005312

Lunn N.J. \& Stirling I. 1985. The significance of supplemental food to polar bears during the ice-free period of Hudson Bay. Canadian Journal of Zoology 63, 22912297.

Obbard M.E., Cattet M.R.L., Howe E.J., Middel K.R., Newton E.J., Kolenosky G.B., Abraham K.F. \& 
Greenwood C.J. 2016. Trends in body condition in polar bears (Ursus maritimus) from the southern Hudson Bay subpopulation in relation to changes in sea ice. Arctic Science 2, 15-32.

Olofsson J. 2006. Short- and long-term effects of changes in reindeer grazing pressure on tundra heath vegetation. Journal of Ecology 94, 431-440.

Onarheim I.H., Smedsrud L.H., Ingvaldsen R.B. \& Nilsen F. 2014. Loss of sea ice during winter north of Svalbard. Tellus Series A 66, article no. 23933, doi: 10.3402/tellusa. v66.23933

Prop J., Aars J., Bardsen B.-J., Hanssen S.A., Bech C., Bourgeon S., de Fouw J., Gabrielsen G.W., Lang J., Noreen E., Oudman T., Sittler B., Stempniewicz L., Tombre I., Wolters E. \& Moe B. 2015. Climate change and the increasing impact of polar bears on bird populations. Frontiers in Ecology and Evolution 3, article no. 33, doi: $10.3389 /$ fevo.2015.00033

Ramsay M.A. \& Hobson K.A. 1991. Polar bears make little use of terrestrial food webs: evidence from stable-carbon isotope analysis. Oecologia 86, 598-600.

Rode K.D., Robbins C.T., Nelson L. \& Amstrup S.C. 2015. Can polar bears use terrestrial foods to offset lost icebased hunting opportunities? Frontiers in Ecology and the Environment 13, 138-145.

Russell R.H. 1975. The food habits of polar bears of James Bay and southwest Hudson Bay in summer and autumn. Arctic 28, 117-129.

Smith T.G. \& Sjare B. 1990. Predation of belugas and narwhals by polar bears in nearshore areas of the Canadian high Arctic. Arctic 43, 99-102.

Stempniewicz L. 1990. Biomass of dovekie excreta in the vicinity of a breeding colony. Colonial Waterbirds 13, 62-66.

Stempniewicz L. 1993. The polar bear Ursus maritimus feeding in a seabird colony in Franz Josef Land. Polar Research 12, 33-36.
Stempniewicz L. 2006. Polar bear predatory behaviour toward molting barnacle geese and nesting glaucous gulls on Spitsbergen. Arctic 59, 247-251.

Stempniewicz L., Kidawa D., Barcikowski M. \& Iliszko L. 2014. Unusual hunting and feeding behaviour of polar bears on Spitsbergen. Polar Record 50, 216-219.

Stirling I. \& Derocher A.E. 2012. Effects of climate warming on polar bears: a review of the evidence. Global Change Biology 18, 2694-2706.

Tartu S., Bourgeon S., Aars J., Andersen M., Ehrich D., Thiemann G.W., Welker J.M. \& Routti H. 2016. geographical area and life history traits influence diet in an Arctic marine predator. PLoS One 11, e0155980, doi: 10.1371/journal.pone. 0155980

Wojciechowska A., Zwolicki A., Barcikowski A. \& Stempniewicz L. 2015. The structure of Cochlearia groenlandica population along the bird colony influence gradient (Hornsund, Spitsbergen). Polar Biology 38, 1919-1930.

Wozencraft W.C. 2005. Order Carnivora. In D.E. Wilson \& D.M. Reeder (eds.): Mammal species of the world: a taxonomic and geographic reference. 3rd edn. Pp. 532628. Baltimore: Johns Hopkins University Press.

Zmudczynska-Skarbek K., Barcikowski M., Zwolicki A., Iliszko L. \& Stempniewicz L. 2013. Variability of polar scurvygrass Cochlearia groenlandica individual traits along a seabird influenced gradient across Spitsbergen tundra. Polar Biology 36, 1659-1669.

Zwolicki A., Zmudczyńska-Skarbek K., Iliszko L. \& Stempniewicz L. 2013. Guano deposition and nutrient enrichment in the vicinity of planktivorous and piscivorous seabird colonies in Spitsbergen. Polar Biology 36, 363-372.

Zwolicki A., Zmudczyńska-Skarbek K., Richard P. \& Stempniewicz L. 2016. Importance of marine-derived nutrients supplied by planktivorous seabirds to High Arctic tundra plant communities. PLoS One 11, e0154950, doi: 10.1371/journal.pone.0154950 